\title{
HIGHER ORDER THINGKING (HOT) PROBLEMS TO DEVELOP CRITICAL THINKING ABILITY AND STUDENT SELF EFFICACY IN LEARNING MATHEMATICS PRIMARY SCHOOLS
}

\author{
Triana Jamilatus Syarifah, Budi Usodo, Riyadi
}

Universitas Sebelas Maret

trianamath@gmail.com

Article History

accepted 09/07/2018

approved 01/08/2018

published 17/09/2018

\section{Keywords}

Higher Order Thingking (HOT), Critical Thinking, Self Efficacy

\begin{abstract}
Kompetensi dalam kurikulum 2013 adalah mengembangkan kreativitas, rasa ingin tahu, kemampuan merumuskan pertanyaan untuk membentuk pikiran kritis yang perlu untuk hidup cerdas dan belajar sepanjang hayat sehingga, siswa perlu dibekali dengan kemampuan-kemampuan tertentu untuk mengembangkan dan mengevaluasi argumen dalam suatu pemecahan masalah tertentu. Salah satu kemampuan yang harus dikembangkan untuk mencapai tujuan tersebut adalah kemampuan berpikir kritis. Kemampuan berpikir kritis adalah kemampuan untuk mengidentifikasi, menganalisis, dan memecahkan masalah secara kreatif dan logis sehingga mampu menghasilkan keputusan yang tepat. Sementara itu, kemampuan berpikir kreatif dipengaruhi oleh keyakinan akan kemampuan diri yang dinamakan self efficacy. Self-efficacy ini berbeda dengan aspirasi (cita-cita), karena cita-cita menggambarkan sesuatu yang ideal yang seharusnya (dapat dicapai), sedang efikasi menggambarkan penilaian kemampuan diri.Untuk mengembangkan kemampuan berpikir kritis dan self efficacy, pembelajaran matematika haruslah mengarah padasoal-soal tidak algoritmik dan komplek dalam menyelesaikan suatu masalah atau tugas, dan juga tidakdapatdiprediksi, pendekatanlatihan yang tepat, ataupetunjuk yang tegas yang disarankanolehtugas, petunjuktugasataucontohjalankeluar. Soal-soal yang seperti itu dikategorikan soal Higher Order Thingking (HOT). Oleh karena itu, soal kategori Higher Order Thingking (HOT) dapat digunakan untuk mengembangkan kemampuan berpikir kritis dan self efficacy siswa dalam pembelajaran matematika siswa di sekolah dasar.
\end{abstract}

Social, Humanities, and Education Studies (SHEs): Conference Series https://jurnal.uns.ac.id/shes
p-ISSN 2620-9284 e-ISSN 2620-9292 


\section{PENDAHULUAN}

Berpikir merupakan suatu keaktifan pribadi manusia yang mengakibatkan penemuan yang terarah kepada suatu tujuan. Berpikir juga merupakan suatu kegiatan mental untuk membangun dan memperoleh pengetahuan. Dalam suatu proses pembelajaran, kemampuan berpikir peserta didik dapat dikembangkan dengan memperkaya pengalaman atau pembelajaran yang memberikan kesempatan kepada peserta didik untuk memperoleh keterampilan-keterampilan, sehingga peserta didik mempunyai struktur konsep yang dapat berguna dalam menganalisis serta mengevaluasi suatu permasalahan.

Salah satu kemampuan berpikir yang perlu diberikan dalam pembelajaran adalah kemampuan berpikir kritis. Kemampuan berpikir kritis adalah kemampuan yang diperlukan peserta didik dalam menghadapi kehidupan yang semakin global. Berpikir kritis merupakan berpikir yang masuk akal, reflektif dan dilakukan secara sistematis terhadap semua informasi atau masalah yang diperoleh sehingga dapat mengambil keputusan yang tepat. Menurut Santrock (2011), berpikir kritis adalah pemikiran reflektif dan produktif, serta melibatkan evaluasi bukti. Jensen (2011) berpendapat bahwa berpikir kritis berarti proses mental yang efektif dan handal, digunakan dalam mengejar pengetahuan yang relevan dan benar tentang dunia. Wijaya (2010) juga mengungkapkan gagasannya mengenai kemampuan berpikir kritis, yaitu kegiatan menganalisis ide atau gagasan kearah yang lebih spesifik, membedakannya secara tajam, memilih, mengidentifikasi, mengkaji dan mengembangkannya kearah yang lebih sempurna.

Kemampuan berpikir kritis tentunya berperan pula dalam proses pembelajaran matematika, karena dengan memiliki kemampuan berpikir kritis, seorang siswa dapat memunculkan ide-ide atau pemikiran baru mengenai suatu permasalahan. Siswa akan dilatih bagaimana menyeleksi berbagai pendapat, sehingga dapat membedakan mana pendapat yang relevan dan tidak relevan, mana pendapat yang benar dan tidak benar. Dengan mengembangkan kemampuan berpikir kritis siswa dapat membantu siswa membuat kesimpulan dengan mempertimbangkan data dan fakta yang terjadi di lapangan.Pentingnya berpikir kritis dalam pembelajaran matematka juga telah diungkapkan oleh pemerintah bahwa:

Kemampuan peserta didik yang diperlukan yaitu antara lain kemampuan berkomunikasi, berpikir kritis dan kreatif dengan mempertimbangkan nilai dan moral Pancasila agar menjadi warga negara yang demokratis dan bertanggungjawab, toleran dalam keberagaman, mampu hidup dalam masyarakat global, memiliki minat luas dalam kehidupan dan kesiapan untuk bekerja, kecerdasan sesuai dengan bakat/ minatnya, dan peduli terhadap lingkungan. (Permendikbud no $81 \mathrm{~A}$ tahun 2013).

Pada kenyataanya, didunia pendidikan kemampuan berpikir kritis siswa masih jauh dari harapan dan tujuan pendidikan. Sehingga diperlukan penelitian lebih lanjut untuk mengetahui faktor - faktor yang berkaitan dengan kemampuan berpikir kritis siswa. kemampuan siswa dalam menyelesaikan permasalahan diduga berkaitan dengan keyakinan diri diwujudkan dalam pola piker dan tindakan rasa ingin tahu, kejujuran, kesediaan menerima pendapat, keterbukaan, kemandirian, dan pengambilan keputusan pada saat pembelajaran. Hal tersebut yang disebut dengan Self efficacy atau keyakinan diri. Hal tersebut juga dipaparkan oleh (Hoffman \& Gregory, 2009) "Some studies found that many different environmental and personal factors are affected the development of critical thinking skills. One group of these factors is socioenvironmental and the other is personal characteristics and motivational beliefs, including among others, self efficacy beliefs "Beberapa penelitian menemukan bahwa banyak factor lingkungan dan pribadi yang berbeda mempengaruhi perkembangan keterampilan berpikir kritis. Faktor-faktor tersebut adalah sosio-lingkungan dan yang 
lainnya adalah karakteristik pribadi dan keyakinan motivasi termasuk antara lain keyakinan self efficacy

Self efficacy adalah salah satu bagian pengetahuan mengenai diri yang berpengaruh terhadap kehidupan manusia. Sawtelle (2012) mendefinisikan self efficacy sebagai kepercayaan diri akan kemampuan sendiri dalam melakukan peran atau tugas tertentu. Selain itu Anwar (2009) juga menyatakan bahwasiswa yang mempunyai derajat self efficacy tinggi akan melaksanakan peran atau tugas tertentu meskipun peran atau tugas tersebut merupakan peran atau tugas yang kompleks, dan menganggap kegagalannya dikarenakan kurangnya keterampilan, pengetahuan, dan usaha

Bandura (Raditiana dan Yorni, 2013) menyatakan bahwa orang-orang dengan keyakinan tinggi memiliki kemampuan untuk mengatasi tugas-tugas yang sulit sebagai tantangan untuk dikuasai daripada menghindari ancaman dan sebaliknya, mereka yang ragu dengan kemampuan mereka akan menghindari tugas sulit karena dianggap sebagai ancaman pribadi, mereka juga memiliki aspirasi yang rendah dan komitmen yang lemah terhadap tujuan yang mereka pilih, sehingga ketika dihadapkan pada tugas yang sulit, mereka tetap pada pola pikir mereka sendiri. Seperti yang disampaikan Wanga and Yi Wub(2008) "self efficacy is a good predictor of using high level learning strategies, such as critical thinking". Self efficacy adalah prediktor yang baik untuk menggunakan strategi pembelajaran tingkat tinggi, seperti pemikiran kritis

Untuk melihat tahapan kemampuan-kemampuan berpikir kritis siswa, guru dapat memberikan latihan soal - soal yang berbeda dengan contoh yang telah diberikan oleh guru. Salah satunya dengan menggunakan soal Higher Order Thinking (HOT). Dapat dikatakan bahwa higher order thinking adalah sesuatu yang tidak algoritmik dan komplek dalam menyelesaikan suatu masalah atau tugas, dan juga tidak dapat diprediksi, pendekatan latihan yang tepat, atau petunjuk yang tegas yang disarankan olehtugas, petunjuk tugas atau contoh jalan keluar. Dengan pemberian soal Higher Order Thinking (HOT) diharapkan pembelajaran matematika di sekolah tidak hanya bersifat menghafal atau mengetahui pengetahuan factual yang cenderung text book, tetapi dapat melatih dan melihat sejauh mana tahapan kemampuan berpikir kritis siswa.

Dalam makalah ini akan dibahas tentang bagaimana kemampuan berpikir kritis dan self efficacy siswa dikembangkan dengan kategori soal Higher Order Thingking (HOT) Terlebih dahulu akan dijabarkan mengenai pengertian, aspek-aspek, dan pentingnya kemampuan berpikir kritis. Selanjutnya akan dibahas mengenai Self Efficacy siswa. Kemudian akan dijabarkan pula pengertian kategori soal Higher Order Thingking (HOT). Terakhir akan dibahas mengenai kemampuan berpikir kritis dan self efficacy yang dikembangkan dengan kategori soal Higher Order Thingking (HOT). Dengan demikian, diharapkan makalah ini berguna sebagai masukan terhadap perkembangan pembelajaran matematika terutama terkait kemampuan berpikir kritis, self efficacy siswa, serta kategori soal Higher Order Thingking (HOT).

\section{METODE}

Metode penelitian ini dilakukan dengan kajian terhadap sejumlah literatur yang dapat mendukung analisis, meliputi kajian tentang kemampuan berpikir kritis, self efficacy, kategori soal Higher Order Thingking (HOT), dan kajian matematika sekolah dasar. Sumber kajian adalah berupa buku referensi terkait, jurnal ilmiah yang dipublikasikan, dan referensi pada website yang diakses melalui internet. Output dari studi literature ini adalah mengenai kemampuan berpikir kritis dan self efficacy dengan kategori soal Higher Order Thingking (HOT) untuk mengembangkan pembelajaran matematika di sekolah dasar yang sesuai dengan perumusan masalah. 


\section{A. Kemampuan Berpikir Kritis}

\section{HASIL DAN PEMBAHASAN}

Beberapa ahli mendefinisikan mengenai pengertian berpikir kritis seperti yang dikemukakan oleh Santrock (2011), pemikiran kritis adalah pemikiran reflektif dan produktif, serta melibatkan evaluasi bukti. Jensen (2011) berpendapat bahwa berpikir kritis berarti proses mental yang efektif dan handal, digunakan dalam mengejar pengetahuan yang relevan dan benar tentang dunia. Sementara itu Wijaya (2010) juga mengungkapkan gagasannya mengenai kemampuan berpikir kritis, yaitu kegiatan menganalisis ide atau gagasan kearah yang lebih spesifik, membedakannya secara tajam, memilih, mengidentifikasi, mengkaji dan mengembangkannya kearah yang lebih sempurna. Berdasarkan beberapa definisi diatas, kemampuan berpikir kritis dapat dikatakan sebagai kemampuan menganalisa gagasan lebih spesifik, memilih, mengidentifikasi dan menguji suatu argumen dalam menyelesaikan permasalahan

Kemampuan berpikir kritis harus dikembangkan dan dilatihkan kepada siswa sejak sekolah dasar. Penguasaan kemampuan berpikir kritis tidak cukup dijadikan sebagai tujuan pendidikan semata, tetapi juga sebagai proses fundamental yang memungkinkan siswa untuk mengatasi ketidaktentuan masa mendatang. Melalui kemampuan berpikir kritis, siswa akan mampu menghadapi fenomena-fenomena di lingkungan sekitar dengan cara mengevaluasi dan mengkronstruksi pemahaman yang ada di dalam diri mereka sendiri. Kemampuan berpikir kritis dapat mendorong siswa memunculkan ide-ide atau pemikiran baru mengenai permasalahan tentang dunia. Siswa akan dilatih bagaimana menyeleksi berbagai pendapat, sehingga dapat membedakan mana pendapat yang relevan dan tidak relevan, mana pendapat yang benar dan tidak benar. Mengembangkan kemampuan berpikir kritis siswa dapat membantu siswa membuat kesimpulan dengan mempertimbangkan data dan fakta yang terjadi di lapangan.

Ennis menyebutkan bahwa kemampuan berpikir kritis yang dikelompokkan menjadi 5 aspek kemampuan berpikir kritis, antara lain: 1) Elementary clarification (memberikan penjelasan dasar) yang meliputi, fokus pada pertanyaan (dapat mengidentifikasi pertanyaan/masalah, dapat mengidentifikasi jawaban yang mungkin, dan apa yang dipikirkan tidak keluar dari masalah itu), Menganalisis pendapat (dapat mengidentifikasi kesimpulan dari masalah itu, dapat mengidentifikasi alasan, dapat menangani hal-hal yang tidak relevan dengan masalah itu), berusaha mengklarifikasi suatu penjelasan melalui tanya-jawab. 2) The basis for the decision (menentukan dasar pengambilan keputusan) yang meliputi, mempertimbangkan apakah sumber dapat dipercaya atau tidak, mengamati dan mempertimbangkan suatu laporan hasil observasi. 3) Inference (menarik kesimpulan) yang meliputi, mendeduksi dan mempertimbangkan hasil deduksi, menginduksi dan mempertimbangkan hasil induksi, membuat dan menentukan pertimbangan nilai. 4) Advanced clarification (memberikan penjelasan lanjut) yang meliputi, mendefinisikan istilah dan mempertimbangkan definisi tersebut, mengidentifikasi asumsi. 5) Supposition and integration (memperkirakan dan menggabungkan) yang meliputi, mempertimbangkan alasan atau asumsi-asumsi yang diragukan tanpa menyertakannya dalam anggapan pemikiran kita, menggabungkan kemampuan dan karakter yang lain dalam penentuan keputusan.

\section{B. Self Effiicacy}

Self-efficacy didefinisikan sebagai keyakinan orang tentang kemampuan mereka untuk menghasilkan tingkat kinerja yang ditunjuk mempunyai pengaruh 
atas peristiwa yang mempengaruhi kehidupan mereka. Keyakinan self-efficacy menentukan bagaimana orang merasa, berpikir, memotivasi diri dan perilakunya Self-efficacy merupakan konstruk yang diajukan Bandura yang berdasarkan teori sosial kognitif. Dalam teorinya, Bandura menyatakan bahwa tindakan manusia merupakan suatu hubungan yang timbal balik antara individu, lingkungan, dan perilaku (triadic reciprocal causation). Teori sosial kognitif menolak pandangan psikoanalisa yang menyatakan manusia merupakan budak dari naluri. Selain itu, ia juga menolak pandangan Behavior yang secara ekslusif menekankan pada aspek lingkungan yang menjadi faktor penentu perilaku manusia. Teori social kognitif menekankan bahwa manusia sebagai individu yang aktif dan menggunakan potensi kognitifnya untuk menggambarkan suatu kejadian, mengantisipasi sesuatu, dan memilih serangkaian tindakan yang akan dilakukan. Teori ini menyatakan manusia bukanlah makhluk yang pasif yang hanya menerima dorongan naluri ataupun pengaruh lingkungan eksternal (Pervin \& Jhon, 2001).

Self-efficacy adalah penilaian diri, apakah dapat melakukan tindakan yang baik atau buruk, tepat atau salah, bisa atau tidak bisa mengerjakan sesuai dengan yang dipersyaratkan. Self-efficacy ini berbeda dengan aspirasi (cita-cita), karena cita-cita menggambarkan sesuatu yang ideal yang seharusnya (dapat dicapai), sedang efikasi menggambarkan penilaian kemampuan diri (Alwisol, 2012) Baron dan Byrne (dalam Ghufron \& Rini, 2010) mendefinisikan self-efficacy sebagai evaluasi seseorang mengenai kemampuan atau kompetensi dirinya untuk melakukan suatu tugas, mencapai suatu tujuan, dan mengatasi hambatan.

Seseorang dengan efikasi diri tinggi percaya bahwa mereka mampu melakukan sesuatu untuk mengubah kejadian-kejadian di sekitarnya, sedangkan seseorang dengan efikasi diri rendah menganggap dirinya pada dasarnya tidak mampu mengerjakan segala sesuatu yang ada di sekitarnya. Dalam situasi yang sulit, orang dengan efikasi diri yang rendah cenderung akan mudah menyerah. Sementara orang dengan efikasi diri yang tinggi akan berusaha lebih keras untuk mengatasi tantangan yang ada. Hal senada juga diungkapkan oleh Gist, yang menunjukkan bukti bahwa perasaan efikasi diri memainkan satu peran penting dalam memotivasi pekerja untuk menyelesaikan pekerjaan yang menantang dalam kaitannya dengan pencapaian tujuan tertentu (Ghufron \& Rini, 2011). Dari beberapa pengertian di atas dapat disimpulkan bahwa self-efficacy adalah keyakinan individu dalam menghadapi dan menyelesaikan masalahyang dihadapinya diberbagai situasi serta mampu menentukan tindakan dalam menyelesaikan tugas atau masalah tertentu, sehingga individu tersebut mampu mengatasi rintangan dan mencapai tujuan yang diharapkan.

\section{Higher Order Thingking (HOT)}

Kemampuan berfikir dasar (lower order thinking) hanya menggunakan kemampuan terbatas pada hal-hal rutin dan bersifat mekanis, misalnya menghafal dan mengulang-ulang informasi yang diberikan sebelumnya. Sementara, kemampuan berfikir tinggi (higher order thinking) merangsang siswa untuk mengintrepretasikan, menganalisa atau bahkan mampu memanipulasi informasi sebelumnya sehingga tidak monoton. Kemampuan berfikir tinggi (higher order thinking) digunakan apabila seseorang menerima informasi baru dan menyimpannya untuk kemudian digunakan atau disusun kembali untuk keperluan problem solving berdasarkan situasi. Dengan demikian, HOTS memberikan dampak pembelajaran bagi peserta didik maupun guru yaitu: (1) belajar akan lebih efektif dengan higher order thinking; (2) meningkatkan kemampuan intelektual guru dalam mengembangkan higher order thinking; (3) dalam evaluasi belajar 
dengan konsep baru ini, guru harus selalu menyiapkan soal pertanyaan yang nantinya tidak dijawab secara sederhana.

Secara umum, keterampilan berfikir terdiri atas empat tingkat, yaitu: menghafal (recall thinking), dasar (basic thinking), kritis (critical thinking) dan kreatif (creative thinking). Tingkat berfikir paling rendah adalah keterampilan menghafal (recall thinking) yang terdiri atas keterampilan yang hampir otomatis atau refleksif. Tingkat berfikir selanjutnya adalah keterampilan dasar (basic thinking). Keterampilan ini meliputi memahami konsep-konsep seperti penjumlahan, pengurangan dan sebagainya termasuk aplikasinya dalam soal-soal. Berfikir kritis adalah berfikir yang memeriksa, menghubungkan, dan mengevaluasi semua aspek dari situasi atau masalah, termasuk di dalamnya mengumpulkan, mengorganisir, mengingat, dan menganalisa informasi. Berfikir kritis termasuk kemampuan membaca dengan pemahaman dan mengidentifikasi materi yang dibutuhkan dan tidak dibutuhkan oleh seseorang. Hal ini juga berarti mampu menarik kesimpulan dari data yang diberikan dan mampu menentukan ketidakkonsistenan dan pertentangan dalam sekelompok data. Berfikir kritis adalah analitis dan refleksif. Berfikir kreatif sifatnya orisinil dan reflektif. Hasil dari keterampilan berfikir ini adalah sesuatu yang kompleks. Kegiatan yang dilakukan diantaranya adalah menyatukan ide, menciptakan ide baru, dan menentukan efektifitasnya. Berfikir kreatif meliputi juga kemampuan menarik kesimpulan yang biasanya menemukan hasil akhir yang baru.

Higher order thinking menghubungkan temuan masalah dan kreativitas melalui kegiatan perencanaan, pengamatan sendiri terhadap perkembangan masalah, dan penyesuaian strategi pemecahan masalah sendiri. Menurut (Heong, dkk, 2011) kemampuan berpikir tingkat tinggi didefinisikan sebagai penggunaan pikiran secara luas untuk menemukan tantangan baru. Kemampuan berpikir tingkat tinggi ini menghendaki seseorang untuk menerapkan informasi baru atau pengetahuan sebelumnya dan memanipulasi informasi untuk menjangkau kemungkinan jawaban dalam situasi yang baru. Dewanto dalam Amalia (2013) menyatakan bahwa kemampuan berpikir tingkat tinggi adalah suatu kapasitas di atas informasi yang diberikan, sikap yang kritis untuk mengevaluasi, mempunyai kesadaran (awareness) metakognitif dan memiliki kemampuan pemecahan masalah. Menurut Stein (2008) berpikir tingkat tinggi menggunakan pemikiran yang kompleks, non algorithmic untuk menyelesaikan suatu tugas, ada yang tidak dapat diprediksi, menggunakan pendekatan yang berbeda dengan tugas yang telah ada dan berbeda dengan contoh.

Berdasarkan beberapa pendapat tersebut dapat ditarik kesimpulan bahwa kemampuan berpikir tingkat tinggi merupakan proses berpikir yang tidak sekedar menghafal dan menyampaikan kembali informasi yang diketahui peserta didik. Kemampuan berpikir tingkat tinggi merupakan kemampuan menghubungkan, memanipulasi, dan menstransformasi pengetahuan serta pengalaman yang sudah dimiliki untuk berpikir secara kritis dan kreatif dalam upaya menentukan keputusan dan memecahkan masalah pada situasi yang baru dan itu semua tidak dapat dilepaskan dari kehidupan sehari-hari.

\section{Soal Kategori Higher Order Thingking (HOT) untuk Mengembangkan Kemampuan Berpikir Kritis dan Self Efficacy Siswa}

Salah satu pembelajaran yang ada dalam sistem pendidikan adalah pembelajaran matematika. Pembelajaran matematika menurut Mulyana dan Sabandar (Moma, 2014) menuntut siswa memiliki kemampuan berpikir kritis, logis, kreatif, sistematis, komunikasi serta kemampuan dalam bekerja sama secara efektif. Salah satu kemampuan berpikir yang harus dimiliki siswa menurut Mulyana dan Sabandar adalah kemampuan berpikir kritis. Salah satu faktor penting yang 
mempengaruhi kemampuan berpikir kritis matematis seseorang adalah selfefficacy. Menurut Alwisol (Rachmawati, 2012) self-efficacy merupakan faktor penting dalam menentukan kontrol diri dan perubahan tingkah perilaku dalam individu.

Self-efficacy berpikir kritis matematis penting bagi siswa karena siswa yang memiliki self-efficacy berpikir kritis matematis tinggi mampu mengatasi masalah menyangkut berpikir kritis dan meningkatkan upaya jika mengalami kesulitan. Menurut Bandura (Anwar, 2009) siswa yang memiliki self efficacy tinggi akan mengerjakan tugas tertentu meskipun tugas tersebut merupakan tugas yang sulit, dan menganggap kegagalan sebagai akibat kurangnya usaha, pengetahuan, dan keterampilan.

Kemampuan berpikir kreatif sangat dipengaruhi keyakinan diri pada siswa itu sendiri. Menurut hasil penelitian Kisti dan Aini (2012) terdapat hubungan yang signifikan antara kretivitas dan self efficacy. Keyakinan diri yang dimaksud adalah self efficacy. Self efficacy merupakan suatu keyakinan dari seseorang untuk menampilkan tindakan baru yang digunakan untuk mengatasi suatu masalah dalam rangka mencapai tujuan.

Untuk mengembangkan kemampuan berpikir kritis dan self efficacy dapatlah diberikan soal-soal tidak algoritmik dan komplek dalam menyelesaikan suatu masalah atau tugas, dan juga tidak dapat diprediksi, pendekatan latihan yang tepat, atau petunjuk yang tegas yang disarankan olehtugas, petunjuk tugas atau contoh jalan keluar. Soal-soal yang seperti itu dikategorikan soal Higher Order Thingking (HOT). Adapun contoh soal - soal yang dapat diberikan sebagai berikut:

1. Soal 1

$$
\begin{aligned}
& \text {------- + ---------+-------+ }=20 \\
& \text {------- + ------- + ---------+-------+ = } 20 \\
& -------+\ldots \ldots \ldots . .+ \text {------- + ---------+ -------+ }=20 \\
& \text { + ------- + ---------+ -------+ ....... } 20
\end{aligned}
$$

2. Soal 2

Perhatikan pola bilangan berikut. Bilangan 2012 akan terletak di bawah huruf ...

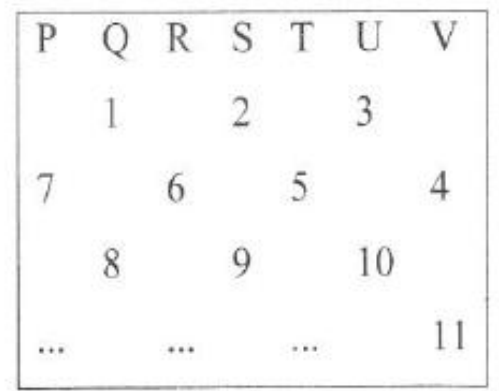

3. Soal 3

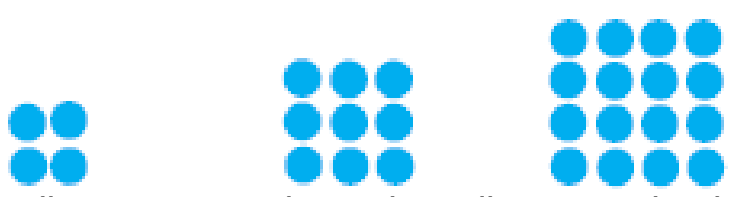

Suatu lingkaran disusun seperti gambar diatas, maka banyaknya susunan lingkaran pada susunan ke 6 adalah? 
4. Soal

Sebuah rumah membutuhkan daya sebesar 5 watt, dan membutuhkan 2 lampu, kemudian apabila rumah tersebut menaikkan kebutuhnnya menjadi 10 watt maka lampu yang dibutuhkan adalah 4 buah. Apabila rumah tersebut membutuhkan 40 watt, berapa lampu yang dibutuhkan?

5. Soal 5

Banyaknya bilangan bulat diantara 1000 dan 2005 yang habis dibagi 13 adalah?

\section{SIMPULAN}

Berdasarkan pembahasan di atas, dapat disimpulkan bahwa berpikir kritis sangat penting bagi siswa untuk menghadapi banyak tantangan yang akan muncul dalam hidup mereka, karier dan tanggung jawab pribadi mereka. Berpikir kritis merupakan kemampuan menelaah atau menganalisis suatu sumber, mengidentifikasi sumber yang relevan dan yang tidak relevan, mengidentifikasi dan mengevaluasi asumsi, menerapkan berbagai strategi untuk membuat keputusan yang sesuai dengan standar penilaian. Sedangkan kemampuan berpikir kreatif merupakan kemampuan berpikir tingkat tinggi yang menuntut siswa untuk mengembangkan ide sehingga menghasilkan sesuatu yang baru dan memberi pemahaman baru terhadap konsep yang ada. Selfefficacy adalah penilaian diri, apakah dapat melakukan tindakan yang baik atau buruk, tepat atau salah, bisa atau tidak bisa mengerjakan sesuai dengan yang dipersyaratkan Pembelajaran dengan kategori soal Higher Order Thingking (HOT) dapat mengembangkan kemampuan berpikir kritis dan self efficacy siswa. Hal ini dikarenakan dalam pembelajaran matematika dengan soal Higher Order Thingking (HOT) adalah pembelajaran yang tidak algoritmik dan komplek dalam menyelesaikan suatu masalah atau tugas, dan juga tidak dapat diprediksi, pendekatan latihan yang tepat, atau petunjuk yang tegas yang disarankan oleh tugas, petunjuk tugas atau contoh jalan keluar.

Berdasarkan hasil pemaparan gagasan yang telah dikemukakan di atas dan dengan berbagai keterbatasan dalam penelitian ini, serta implikasinya dalam upaya peningkatan pemahaman konsep matematis, berikut ini dikemukakan saran sebagai berikut:

1. Disarankan kepada guru agar dalam proses pembelajaran, sebaiknya menggunakan soal kategori Higher Order Thinking (HOT) sehingga dapat mengembangkan kemampuan berpikir kritis dan self efficacy siswa

2. Kepada peneliti selanjutnya yang ingin mengkaji penelitian yang serupa agar melakukan penelitian dan pengkajian yang lebih dalam dengan referensi yang lebih lengkap.

\section{DAFTAR PUSTAKA}

Amalia, Riski. 2013. Penerapan Model Pembelajaran Pembuktian Untuk Meningkatkan Kemampuan Berpikir Matematis Tingkat Tinggi Siswa SMA. Skripsi, Universitas Pendidikan Indonesia, Bandung Aunurrahman

Anwar, A. I. D. (2009). Hubungan Antara Self-Efficacy Dengan Kecemasan Berbicara Di Depan Umum Pada Mahasiswa Fakultas Psikologi Iniversitas Sumatera Utara. Skripsi. Medan: Universitas Sumatera Utara

Cece Wijaya. (2010). Pendidikan Remidial Sarana Pengembangan Mutu Sumber Daya Manusia. Bandung: PT. Remaja Rosdakarya. 
Heong, Y.M, dkk. (2011). "The Level of Marzano Higher Order Thingking Skills Among Technical Education Students". International Journal of Social and Humanity. 1 (2). $121-125$

Jensen, Eric. (2011). Pembelajaran Berbasis Otak (Edisi Kedua). Jakarta. PT Indeks Permata Puri Media

Kemdikbud. (2013). Permendikbud 81A tahun 2013 tentanglmplementasiKurikulum 2013. Jakarta: KementrianPendidikandanKebudayaan.

Raditiana, Yorni. (2013). Pengembangan Model Peer Guidance untuk Meningkatkan Self Efficacy Siswa Kelas VIII H SMP Negeri 2 Salatiga. http://repository.uksw.edu/handle/123456789/3572.

Santrock, John W. (2011). Perkembangan Anak Edisi 7 Jilid 2. (Terjemahan: Sarah Genis B) Jakarta: Erlangga.

Sawtelle V, Brewe E, Kramer LH. (2012). Exploring The Relationship between SelfEfficacy and Retention in Introductory Physics. Journal of Research in Science Teaching:1096-1121

Wanga, Shu Ling= Yi Wub, Pei. (2008). The role of feedback and self-efficacy on webbased learning:The social cognitive perspective, Computers \& Education. 51, 1589-1598. 